\title{
MASS MORTALITY AS A WAY OF STRUCTURING AMAZONIAN AND ALPINE TREE POPULATIONS: EVIDENCE AFTER STORM VAIA
}

\author{
EDGARDO I. GARRIDO-PEREZ ${ }^{1}$, JUAN G. LINCANGO-VEGA ${ }^{1}$, DAVID TELLA-RUIZ ${ }^{1}$, MARIA I. ARIAS-PIZARRO ${ }^{1}$, \\ KAREN BONILLA $^{1,2}$, JAIRO CABRERA ${ }^{1,2}$, HORUS J. ROMAN ${ }^{3}$
}

1Asociació Llapis i Llavors, Calle Aragó 565 bajos, Barcelona, Spain; e-mail: edgardoga2@hotmail.com, jglv83@hotmail.com, davidtr70@gmail.com, miap.1997@gmail.com

${ }^{2}$ Universidad Regional Amazónica -Ikiam, vía Muyuna km.7, Tena 150150, Napo, Ecuador; e-mail: karenb98@gmail.com, jairocabrera87@hotmail.com

${ }^{3}$ Universidad Yachay Tech, San Miguel de Urcuquí, Hacienda San José s/n, Imbabura, Ecuador

$\triangle$ Corresponding author

Received: 6 November 2019 / Accepted: 4 February 2020

\begin{abstract}
Garrido-Perez E.I., Lincango-Vega J.G., Tella-Ruiz D., Arias-Pizarro M.I., Bonilla K., Cabrera J., Roman H.J.: Mass mortality as a way of structuring Amazonian and alpine tree populations: evidence after storm Vaia. Ekológia (Bratislava), Vol. 40, No. 1, p. 37-47, 2021.

By logging in the past, humans can determine current tree population structures, but fast stump decomposition makes difficult to falsify that for Amazonian Rainforests. We reconstructed land-use histories and surveyed trees $\geq 10 \mathrm{~cm}$ diameter at breast height on three 1-ha plots (K1, K2, and K6) in Kühbergl, South Tyrolean Alps as we did for four plots in Atacapi, Ecuador (plots A, B, C, and D). Storm Vaia (October 27 -November 1, 2018) stroke Kübergl providing dated evidence of mass tree-mortality on plot K6. We used K6 as control for comparing its pre- and post-storm population structures with the ones of four Amazonian, and three Alpine species where Vaia did not kill trees (Kolmogorov-Smirnov tests). When compared with K6's Picea abies, the following species had size distributions similar to post-storm, but not to pre-storm situation. Amazonian: Piptocoma discolor, Vochysia bracelineae (plots B and D), Miconia decurrens (plots B and C), and Pseudobombax sp (plot C). Alpine: Larix decidua (plot K1) and Picea abies (plot K2). Storms do not occur in Atacapi, where logging is a common practice. That makes plausible that discrete events of compulsive logging during secondary succession made Amazonian population structures to look similar to K6's P. abies. Logging is forbidden in Kühbergl, but storms are common there. Thus, the current population structures of Larix decidua (plot K1) and Picea abies (plot K2) should be legacies of storms before Vaia. Looking into tree populations' history can impulse research for answering some basic questions of Ecology: what alters population structures, and which population structuring processes are more influential than others.
\end{abstract}

Key words: alpine wet tundra, disturbance, land-use history, tree sizes, tropical rainforest.

\section{Introduction}

Historical ecology is a multidisciplinary research field discovering how past human interventions determine the current status of landscapes and ecosystems (Bürgi et al., 2016), biodiversity, and species compositions at regional and single forest levels (Garrido-Pérez et al., 2017; Levis et al., 2017). By revealing past economic and socio-political processes determining environmental change, Historical Ecology proposes measures for conserving nature by showing how to conciliate local interests with institutional plans (Szabó, Hédl, 2011; Garrido-Pérez et al., 2018). Yet, Historical Ecology has barely assessed the effects of past land-uses on the structure and vigor of current tree populations. For instance, individual cash crop trees submitted to moderate pruning do not suffer significant vigor reduction (e.g., Víquez, Pérez, 2005). Such a "biographic" information on individual trees imply that the populations of moderately pruned individuals should not decline after further land abandonment. In contrast, mortality by clear-cutting and compulsive selec- tive logging in the past may have altered current structures of tree-populations. Such changes are not well-known because of the fast decomposition of dead plants in the tropics, due to high moisture and temperatures (Jenny et al., 1949; Thaiutsa, Granger, 1979). Storms supply clearly dated events of tree mortality. Thus, tree populations subjected to storms are useful control groups for comparing with other populations. That should enhance the knowledge of the history of forests by adding information on their populations.

\section{Considering populations for filling gaps of land-use histories}

We have published the exhaustive historical account of four secondary, terra firme Amazonian Tropical Rainforest in Ecuador (Garrido-Pérez et al., 2017, 2018). There, we report that: (a) land-uses including cattle and cash crop oligocultures prior to land abandonment resulted in increased captures of $\mathrm{CO}_{2}$ after some $22 \mathrm{y}$ of secondary succession. That was a short time com- 


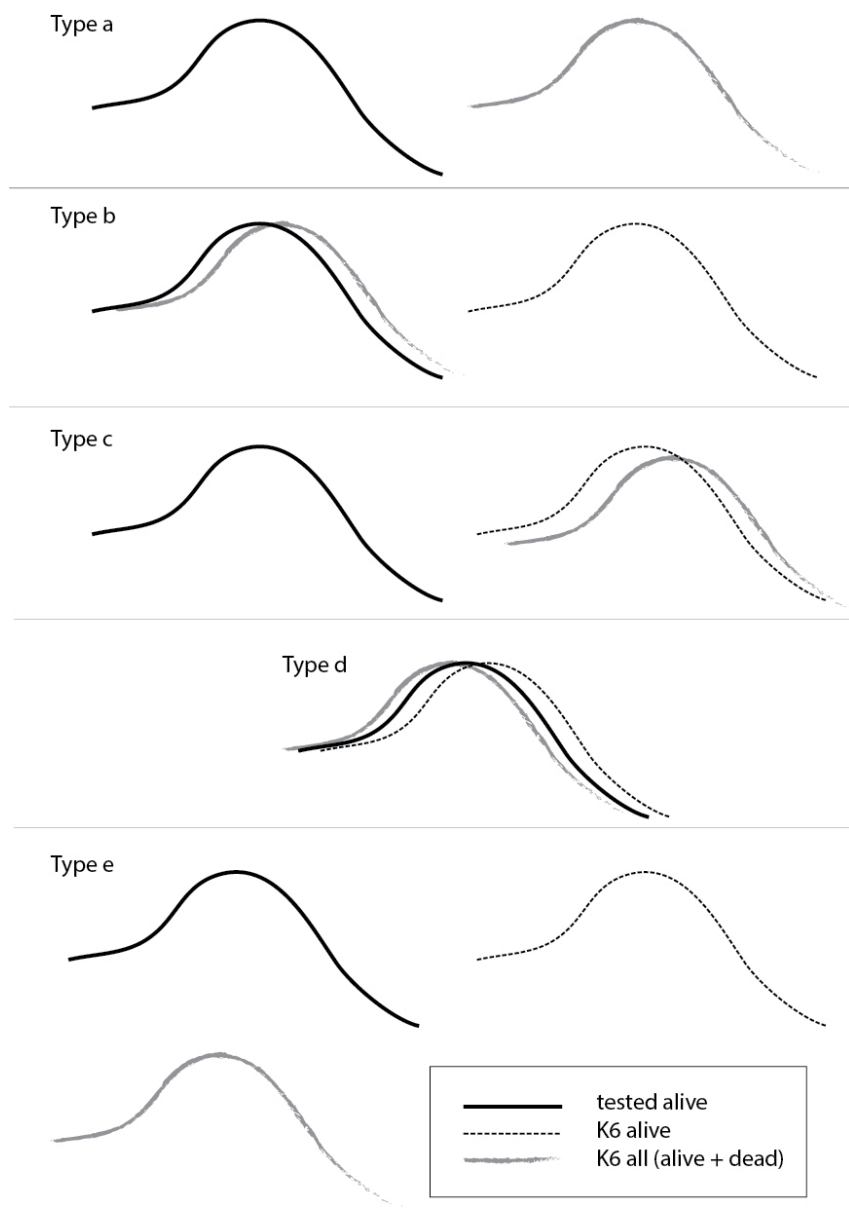

Fig. 1. Five possible outcomes when comparing instant population structures of adult trees in the tested tree-populations in the Amazon (Atacapi, Ecuador) and the Alps (Kühbergl, Italy) vs our Alpine plot K6 -where the date of mass mortality was known (October 27 to November 1, 2018). (a) Mass death in K6 caused similarity with the population being tested (Amazon or Alps), suggesting an important role of mass mortality for the tested population. (b) Mass death in K6 generated difference with respect to the tested population, so the processes other than mass death (e.g., recruitment, gradual mortality) may have played a major role in the tested population. (c) Mass death reduced K6 population size without altering structure there. That suggests a proportional mortality due to strong winds for each size class with respect to the others, yet no cause of death is inferred for the tested population. (d) Situations b and c occur simultaneously. (e) Mass death and the combination of other processes did not eclipse the role of each other for the K6 population; no cause of death can be inferred for the tested population.

pared to another, $\sim 37 \mathrm{y}$-old stand used for traditional, Kichwa indigenous agriculture (named chakra-ushun-purun). There, landusers cultivated some 50 plant species, but kept a comparatively small above-ground biomass. (b) The most plausible explanation for lowered biomass was that the chakra-ushun-purun land-use involves recurrent selective logging during succession, for example, for repairing house and fence. (c) The diversity of trees was higher for the chakra-ushun-purun stand compared to the others. That may have occurred because land-users were not only producing cash crops for the market, but also a wide range of items for self-consumption including food, medicine and housing. (d) Besides the later, chakra-ushun-purun farmers practiced selective logging; that opened gaps and thereby enhanced biodiversity during further secondary succession (Garrido-Pérez et al., 2017, 2018). All just mentioned findings answer questions at the ecosystem and community levels. But what have been the impacts of past land-use on current structures of tree populations in our Amazonian study site? In order to address this we compare the population structures of: (a) four Amazonian tree species for which dead individuals were not visible in the field against (b): three Alpine tree species for which stumps of dead individuals were clearly recognizable during a still ongoing census made by ourselves.

\section{Storm Vaia provides an experimental control group}

Moreover, during late October 2018, the storm Vaia (winds up to $130 \mathrm{~km} \mathrm{~h}^{-1}$, Autonome Provinz Bozen-Südtirol, 2019) stroke our Alpine study area in South Tyrol, Italy, producing mass mortality on one of our plots. That provided a clear, precise date of death for many visible individuals. We decided to use the population structures of species on the stroke plot as control groups to be compared with populations on plots non-stroke by the storm. We made that in order to falsify the hypothesis that mass mortality played a major role structuring tree populations in both the Amazon and the Alps.

Birth and immigration produce recruitment and transitions from one size class to the following ones. At the same time, mortality reduces the numbers of individuals able to perform such transitions (see also Saha et al., 2017). If all these are true, then the current tree population structures are snap shots of the changing frequency distributions generated by the just mentioned processes during the past (Rockwood, 2006; see also Bongers et al., 1988). Repeated census studies are needed for assessing the structuring role played by recruitment and transitions (e.g., Pérez-Paredes et al., 2014). Yet we propose that the role of mass death can be falsified by looking into population structures including- and excluding trees felled by strong winds. Accordingly, our expected outcomes for this study are shown and explained in Fig. 1.

\section{Material and methods}

\section{Study sites, and sampling tree-populations}

Our Amazonian secondary, Terra Firme sites correspond to Tropical Rainforests (sensu Holdridge et al., 1971; Af sensu Köppen; Kottek et al., 2006). The site is located in Atacapi, Canton of Tena, Napo, Ecuador ( 7km from Tena City); nearby rivers are Colonso, Pashimbi, and Tena (Fig. 2a). Altitude is $\sim 650$ m.a.s.l., annual rainfalls are $\sim 4100 \mathrm{~m}$ year $^{-1}$ for nearby Jatun Sacha (Clinebell et al., 1995); temperatures average $23^{\circ} \mathrm{C}$ (World Climate Data, 2019a). Soils are well-drained inceptisols (MAGAP, 2011). Four 1 ha-plots $(50 \times 200 \mathrm{~m})$ were randomly settled, and delimited following terrain's contour. Plot A was 200 m away of Tena River and other $\sim 200 \mathrm{~m}$ away of Pashimbi River. Plot B was $\sim 100 \mathrm{~m}$ away from Pashimbi and $\sim 200 \mathrm{~m}$ away of Colonso River. Plot $\mathrm{C}$ was $\sim 200 \mathrm{~m}$ from Pashimbi River, and Plot D was $\sim 600 \mathrm{~m}$ away from Tena River. All the trees having diameter more than 
(a)

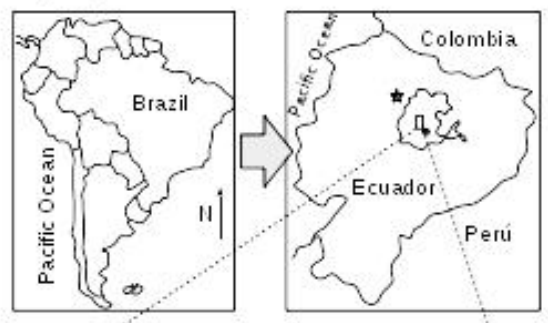

$77^{\circ} 51^{\prime} 53^{\prime \prime} \mathrm{W}$

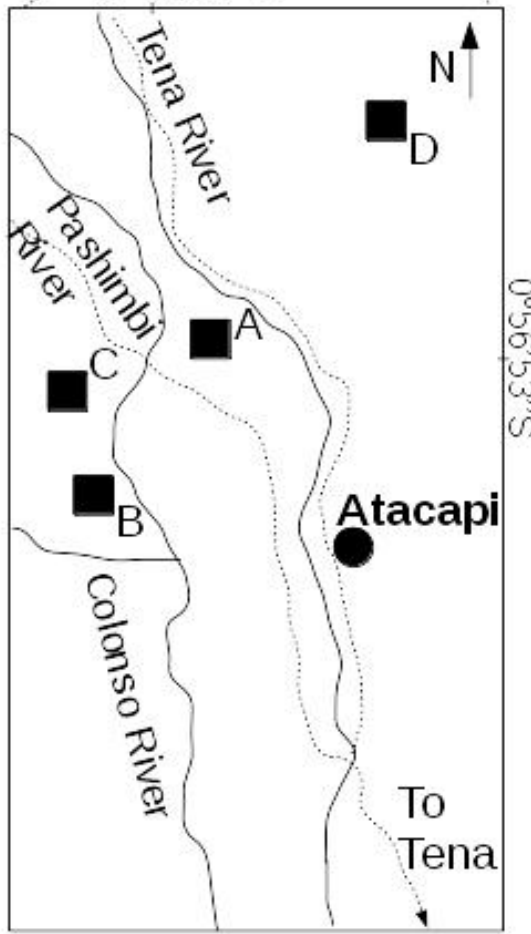

(b)

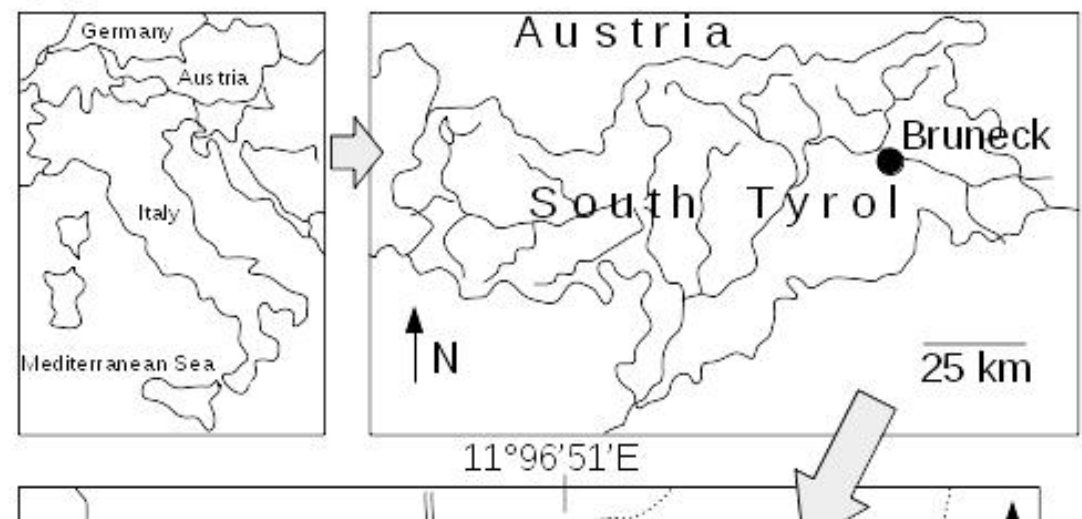

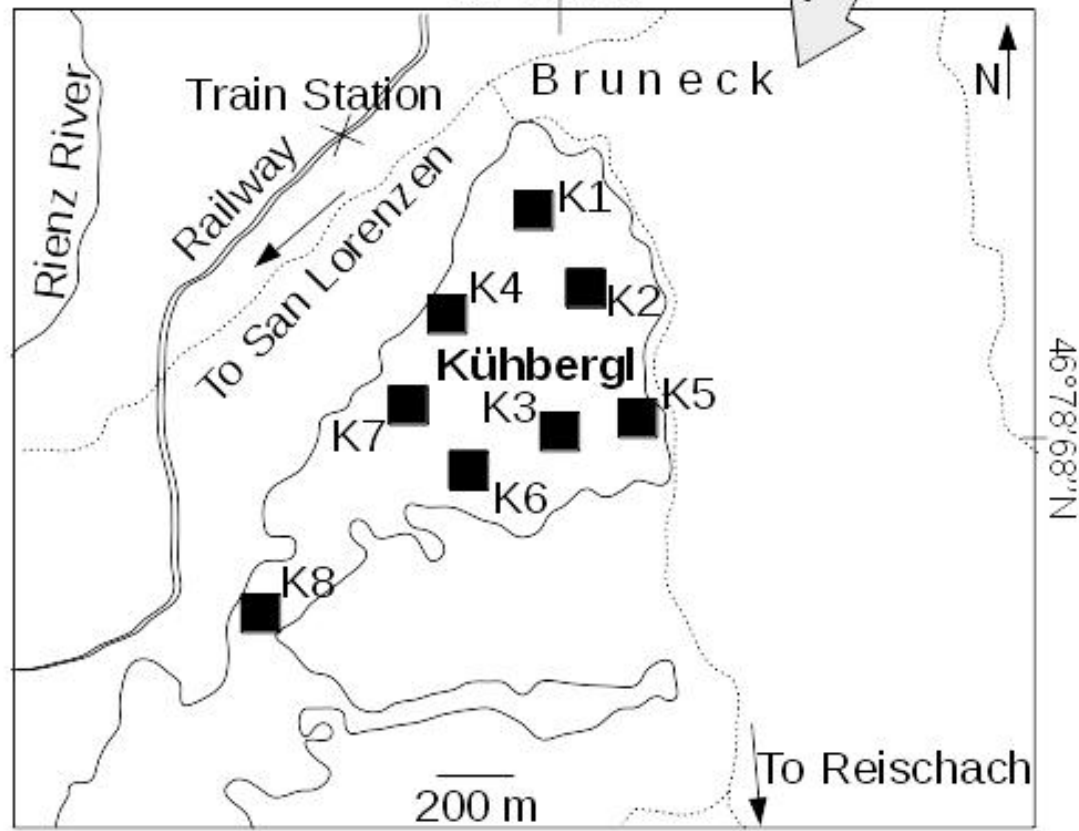

Fig. 2. Location of Amazonian (a) and Alpine (b) one hectare forest plots for measuring and identifying trees $\geq 10 \mathrm{~cm}$ diameter at breast height. Only plot K6 suffered mass mortality due to storm Vaia (October 27 to November 1, 2018). Therefore, we used such a plot as control for falsifying mass mortality as a way of structuring the populations of both Amazonian and Alpine trees according to Fig. 1. The survey of the Alpine plots is still taking place so only results from plots $\mathrm{K} 1, \mathrm{~K} 2$ and $\mathrm{K} 6$ are reported here.

or equal to $10 \mathrm{~cm}$ at breast height $(\mathrm{dbh}=1.3 \mathrm{~m}$ above ground level) were measured and identified as part of another study (Garrido-Pérez et al., 2017, 2018). Here we decided to assess the population structures of trees having $\mathrm{dbh} \geq 10 \mathrm{~cm}$ individuals on at least one plot. Before fallowing, Amazonian plots A (12-15 y-old forest), B (22-25 y-old forest), and C (35-37 y-old forest) were used for cattling and oligocultures of perennial plants (see Table 1 for species and periods for such activities). Moreover, plots B and C were also used for housing. Plot D (35-40 y-old forest) was used for Kichwa indigenous agriculture chakraushun-purun (Table 1). Such a shifting agriculture includes the following. (a) Chakra: clear-cutting by slash-mulch and-burn while collecting seeds of food and wood species from the forest in order to nurse them. During chakra, species to be harvested before one year-mainly Manihot esculenta Crantz (Euphorbiaceae) are planted. (b) Ushun is the second period, starting at the end of the first M. esculenta harvest (nine months after planting). Then, other short-cycle species (harvest before one year after planting) are put again, but combined with other, longerliving species taken from the previously made nursery. Together, chakra and ushun periods comprehend $>50$ plant species in the crop, mainly perennials. Finally (c): Purun is a period starting at approximately the sixth year from the beginning of the whole process. A purun place is a secondary forest used for selectively extracting wood and non-wood resources during succession. All these while training kids about the plants and processes of the forest and how to sustainably use them by means of traditional methods (Vitery, 2015). Therefore, selective logging during purun in the past may have affected current population structures of target tree species. Also, remnant trees kept after clear-cutting for chakra should be reflected as big trees in the current population structures of their species. 
Table 1. Summarized land-use histories (1970-2015) of four 1 ha plots (A, B, C and D) on secondary, Terra Firme forests in Atacapi, province of Napo, Ecuadorian Amazon (after Garrido-Pérez et al., 2018). Chakra, ushun and purun are Kichwa-indigenous words for the three periods of planting, cultivating and harvesting of more than 50 species during shifting agriculture and fallow management. Taxa mentioned by common names: citrus = Citrus spp., Rutaceae; coffee = Coffea canephora Pierre ex A. Froehner, Rubiaceae; manihoc = Manihot esculenta Crantz, Euporbiaceae; plantain = Musa spp., Musaceae; guayusa = Ilex guayusa Loes., Aquifoliaceae.

\begin{tabular}{|c|c|c|c|c|}
\hline $\begin{array}{l}\text { Date } \\
\text { (A.D) }\end{array}$ & Plot A & Plot B & Plot C & Plot D \\
\hline 1970-1980 & Abundant cattle. & Abundant cattle. & $\begin{array}{l}\text { Abundant cattle and horses. } \\
\text { Big house with stable } \\
\text { included. Abundant citrus, } \\
\text { and fruit trees in oligo- } \\
\text { culture; therefore: thinning. }\end{array}$ & $\begin{array}{l}\text { Forest until } 1971 \text { - date } \\
\text { of clear-cutting. Then } \\
\text { chakra per nine months } \\
\text { (until 1972). Then } \text { ushun } \\
\text { per five years (1972-1976). } \\
\text { About } 50 \text { planted species } \\
\text { during chakra and ushun } \\
\text { including edible and wood- } \\
\text { producing trees. Finally, } \\
\text { purun-managed fallow used } \\
\text { for selective logging and } \\
\text { extraction of non-wood } \\
\text { resources (1976-2015). }\end{array}$ \\
\hline 1980-1992 & $\begin{array}{l}\text { Cattle on half of the plot's } \\
\text { area. On the second half: } \\
\text { oligoculture with mainly } \\
\text { coffee and citrus. Thinning } \\
\text { was common, an unknown } \\
\text { pesticide was used only once. }\end{array}$ & $\begin{array}{l}\text { Oligoculture: mainly } \\
\text { manihoc, plantain, citrus, } \\
\text { and guayusa. Cattle. Small } \\
\text { livestock (pigs). Small house } \\
\text { for one person. }\end{array}$ & Fallow (1980-2015). & $\begin{array}{l}\text { Purun-managed fallow, } \\
\text { including selective logging } \\
\text { and extraction. }\end{array}$ \\
\hline $1992-2001$ & $\begin{array}{l}\text { Cattle on half of plot's } \\
\text { area. On the second half: } \\
\text { oligoculture -mainly coffee } \\
\text { and citrus; thinning was } \\
\text { common. }\end{array}$ & Fallow. & Fallow. & $\begin{array}{l}\text { Purun-managed fallow, } \\
\text { including selective logging } \\
\text { and extraction. }\end{array}$ \\
\hline $2001-2015$ & $\begin{array}{l}\text { Fallow with thinning and } \\
\text { weeding. }\end{array}$ & Fallow. & Fallow. & $\begin{array}{l}\text { Purun-managed fallow, } \\
\text { including selective logging } \\
\text { and extraction. }\end{array}$ \\
\hline
\end{tabular}

Our Alpine forest site is a hill called Kühbergl, Municipality of Bruneck, South Tyrol, Italian Alps (Fig. 2b). Altitude is $~ 920$ m.a.s.l., precipitations are $850 \mathrm{~mm}$ year ${ }^{-1}$, mean temperatures range from $-3.3^{\circ} \mathrm{C}$ (January) to $17.5^{\circ} \mathrm{C}$ (July; World Climate Data, 2019b). Life zone is Alpine Wet Tundra (sensu Holdridge et al., 1971); Snow climate-fully humid (Dfb) sensu Köppen (Kottek et al., 2006). Wind speed averages $18.5 \mathrm{~km} \mathrm{~h}^{-1}$ (Global Wind Atlas, 2018), but reached up to $130 \mathrm{~km} \mathrm{~h}^{-1}$ during storm Vaia (October 27-29, 2018; Autonome Provinz Bozen-Südtirol, 2019). Storm Vaia did not evenly affect all places due to the changing, mountainous topography. Soils are well drained cambisols on slate and dolomitic rock. Both clear-cutting and logging are strictly forbidden. However, when trees fell naturally, companies are allowed to remove trees by suspending them using cranes and cables thereby lowering extraction's impact. Local inhabitants are allowed to practice extractivism (firewood, branches, herbaceous plants, flowers) using their hands and instruments other than chain chaw. While our Alpine forest plot surveys and land-use history reconstructions are still on motion, we decided to identify and measure at least 130 individual trees $\geq 10 \mathrm{~cm}$ dbh from three plots as follows. Plot K1 was settled on an abandoned pasture used for summerly grazing by livestock of the community of Bruneck from at least 1581, presumably until c.a. 1825 when it became a summer cabin-and-garden until c.a. 1944 (Land Tirol, 2019a,b; Oberhofer, 2017; dates are still being determined). Such a stand is currently dominated by Larix decidua Mill. (Pinaceae) including both living individuals and stumps with different degrees of decomposition, but virtually most of them poorly putrid thanks to seasonally freezing temperatures and comparatively dry summers respect to the tropics. Plot K2 was located on a mixed stand including three Pinaceae: L. decidua, Picea abies L. and Pinus sylvestris; all them with stumps with different degrees of decomposition. Finally, Plot K6 was the one struck by the strong winds of October 27-29. Species as such contribute to buffer the impact of precipitations (Mikloš et al., 2017), thereby reducing soil erosion. We established such a plot on a stand facing the village of Raischach (Riscone), including mainly Picea abies and Pinus sylvestris on an area forested since at least 1581 (Land Tirol, 2019a,b). Plot K6 was strongly struck by the aforementioned strong winds of October 29, 2018, so the death date of fell trees was clearly recognizable by looking into both fell trees and very fresh stumps remaining after the fell-tree extraction made by companies. 
Table 2. Pearson's correlations between diameter at $5 \mathrm{~cm}$ above ground level $\left(\mathrm{d}_{\mathrm{foot}}\right)$ and diameter at breast height $(\mathrm{dbh}$, at $1.30 \mathrm{~m}$ above ground level) for three sampled tree species in three plots in Kühbergl, Bruneck, South Tyrol, Italian Alps. All plots had well preserved stumps of dead trees so $d_{\text {foot }}$ of such stumps is useful for estimating their dbh at the moment they died. Plot K6 suffered mass death of trees due to strong winds (October 27 to November 1, 2018). Plots are named after another, ongoing research.

\begin{tabular}{|l|c|c|c|c|c|}
\hline Species & Plot & $\begin{array}{c}\text { Number of living } \\
\text { individuals }\end{array}$ & Pearson's r & $\mathbf{R}^{\mathbf{2}}$ & Formula for estimating dbh \\
\hline Larix decidua Mill. (Pinnaceae) & $\mathrm{K} 1$ & 39 & 0.94 & 0.89 & $\mathrm{dbh}=-4.81+0.81 \mathrm{~d}_{\text {foot }}$ \\
\hline Larix decidua & $\mathrm{K} 2$ & 35 & 0.98 & 0.97 & $\mathrm{dbh}=0.04+0.77 \mathrm{~d}_{\text {foot }}$ \\
\hline Picea abies L. (Pinaceae) & K2 & 43 & 0.99 & 0.99 & $\mathrm{dbh}=1.22+0.76 \mathrm{~d}_{\text {foot }}$ \\
\hline Pinus sylvestris L. (Pinaceae) & K2 & 20 & 0.99 & 0.99 & $\mathrm{dbh}=-5.26+0.95 \mathrm{~d}_{\text {foot }}$ \\
\hline Picea abies & K6 & 34 & 0.99 & 0.98 & $\mathrm{dbh}=0.71+0.78 \mathrm{~d}_{\text {foot }}$ \\
\hline Pinus sylvestris & K6 & 43 & 0.96 & 0.93 & $\mathrm{dbh}=2.24+0.78 \mathrm{~d}_{\text {foot }}$ \\
\hline
\end{tabular}

Stumps of Alpine trees were identified and measured at $~ 15$ $\mathrm{cm}$ above ground level (foot diameter $=\mathrm{d}_{\text {foot }}$ ). Living individuals were identified and their diameters were measured two times: at breast height (dbh), and at ground level. By means of Pearson correlations, we determined to what extent foot diameters of living Alpine trees are a good proxy for their dbh, then we ran linear regressions in order to achieve formulae for estimating the dbh of dead trees from the diameters of their stumps. Such a procedure enabled us to draw population structures of the studied Alpine tree species excluding and including the dead trees. For both the Amazon and the Alps, tree sizes were grouped in diameter classes every $3 \mathrm{~cm}$ in order to try to detect the effects of any mortality agents occurring in short periods. We considered the intervals $<3 \mathrm{~cm}$ to be potentially affected by girth oscillations due to water storage inside the trunks (capacitance; Meinzer et al., 2004). We used Kolmogorov-Smirnov (KS) tests in order to detect similarities among population structures. For interpreting the outputs of KS tests according to Fig. 1, we applied the following step-by-step procedure (Fig. 3).

\section{Results}

The total number of studied trees was 1,142 (Amazonian trees = 697, Alpine trees $=445$ ). No dead individuals were found in the Amazon. Whereas, the Alpine area had 275 living trees and 170 dead ones. Numbers of studied individuals for the Amazonian plots were: Plot $A=144$, plot $B=242$, plot $C=236$, and plot $D$ $=75$. Total Alpine studied trees per plot were: plot $\mathrm{K} 1=80$, plot $\mathrm{K} 2=190$, and plot K6 = 175 individuals. For all Alpine plots and studied species, $d_{\text {foot }}$ was a very good predictor of $\mathrm{dbh}$ (Pearson correlations, $r>0.90$, Table 2).

Storm Vaia made Pinus sylvestris on plot K6 to reduce its population size while keeping the size structure (KolmogorovSmirnov, D = 0.4, $\mathrm{p}=0.1$, Fig. $4 \mathrm{a}$ ). When using P. sylvestris_K6 as a control group, size-class change response type $d$ occurred for almost all Amazonian and Alpine species. That suggests that our data reject the possibility of mass death as a major structurer of populations, while no-cause of population structuring can be inferred with these data. All these is valid for Piptocoma discolor_B which had a size-class change response type $\mathrm{c}$ when comparing with Pinus sylvestris_K6 (Appendix). As well as for P. sylvestris_K6, our Picea abies_K6 suffered population size reduction without changing its distribution of size-classes (Kolmogorov-
Compare your K6 population alive (after strong winds) vs K6 all (including and excluding dead individuals). Are they similar?

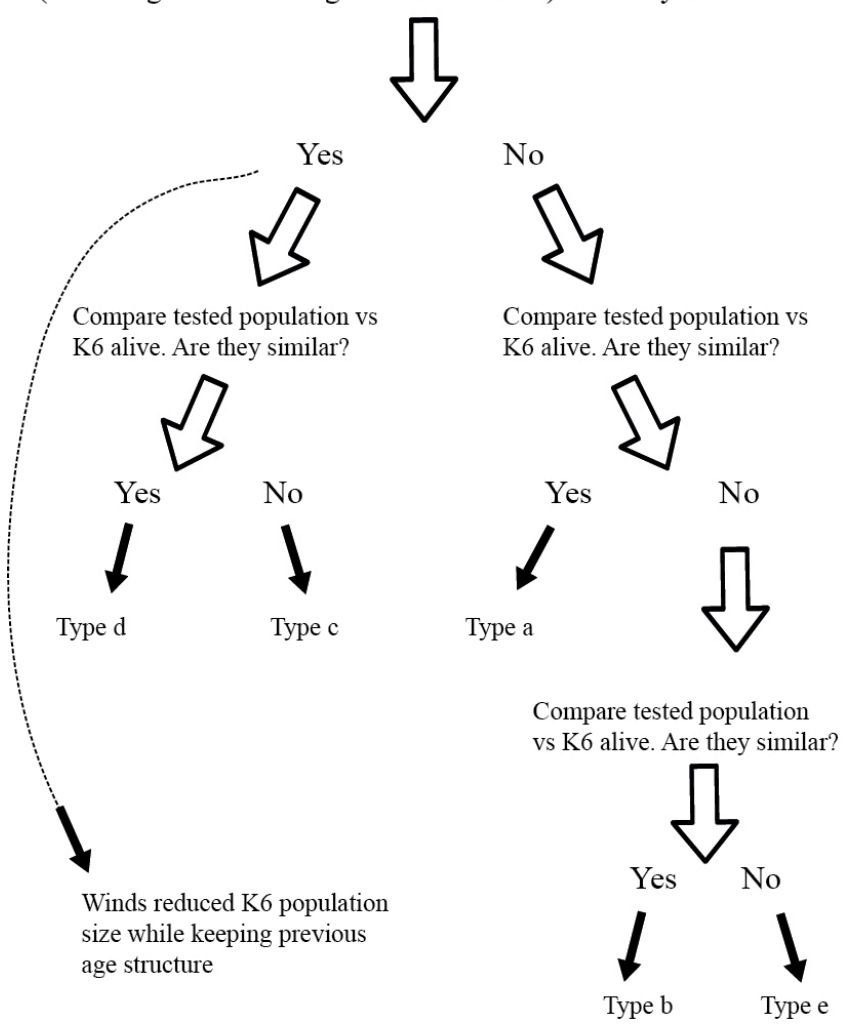

Fig. 3. Dichotomous key for interpreting comparisons of age structure of tree-populations (size distributions)-between an Alpine population (K6) suffering mass mortality due to storm Vaia (October 27 to November 1, 2018) vs other Alpine and Amazonian tree-population structures. Types $\mathrm{a}, \mathrm{b}, \mathrm{c}, \mathrm{d}$ and e are comparisonresponses after running Kolmogorov-Smirnov tests (Fig. 1).

Smirnov, D = 0.1, $\mathrm{p}=0.9$, Fig. $4 \mathrm{~b})$. However, when comparing P. abies_K6 with other population structures, size-class change responses were different to the ones obtained when using Pinus sylvestris_K6 as control group. The later suggests there were two different versions of the history of the effects of mass death when using different tree species as "witnesses" for inferring populations' histories. In concrete, using Picea abies_K6 resulted in type 

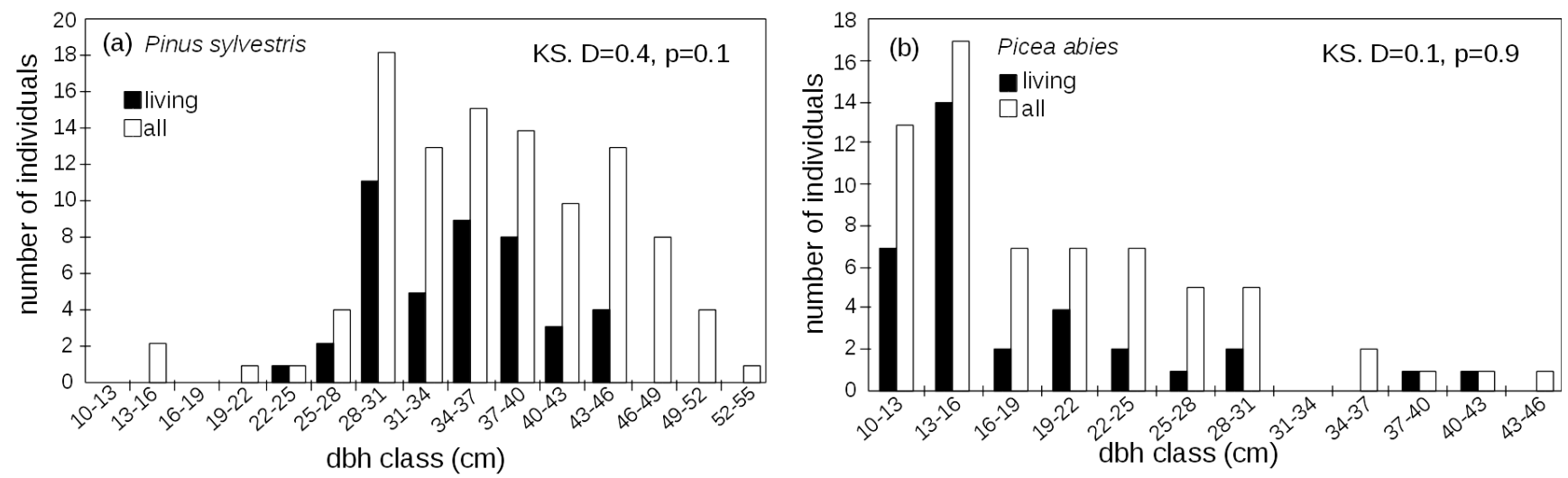

Fig. 4. Size-class frequencies for the Alpine Pinaceae tree species: (a) Pinus sylvestris L., and (b) Picea abies L. and on a one hectare plot (K6) in Kühbergl, South Tyrol, Italy. Living = individuals excluding stumps, and all = including both living and dead individuals. dbh $=$ diameter at breast height (1.3 $\mathrm{m}$ above ground level). All the dead trees fell down by strong winds during storm Vaia (October 27 to November 1, 2018).

a response for many of our Alpine and Amazonian species, pointing to the plausibility of mass mortality during population structuring in both sites. Thus, Alpine species with size-class change responses type a were: Larix decidua_K1 - where only living trees were seen, L. decidua_K2, and Picea abies_K2 - both of them after including and excluding dead trees for the analyses (Appendix, Fig. 5). Also, almost all the Amazonian species and plots generated type a-responses when compared to P. abies_K6. Such Amazonian species and their plots were: Piptocoma discolor_B and D, Vochysia bracelineae_B and D, as well as Miconia decurrens_B and C, and Pseudobombax sp._C. Only Piptocoma discolor_A and Vochysia bracelineae_C had size-class change response type e (Appendix, Fig. 5).

Finally, size-class structures were similar among the Amazonian species when compared to each other for 26 of the 36 possible comparisons (Appendix). That puts on the table the feasibility of similar histories leading to their population structures. Yet Piptocoma discolor_A had a size class structure different to most of the other species and plots (Appendix). This suggests that the young age of $P$. discolor_A (the forest was only 12-15 y-old) did not give enough time for death to play any detectable role. For plot C, Vochysia bracelineae's size distribution was different compared to the same species on plot D (Appendix), potentially due to mass mortality of the species on plot C. However, significant differences for $V$. bracelineae on plots B $v s \mathrm{C}$ (Appendix) are not understandable by looking into such a table. Yet comparing $V$. bracelineae of plot B with all our Alpine species on plot K6 suggests that processes other than mass mortality structured the population of $V$. bracelineae inside our Amazonian plot B (Appendix).

\section{Discussion}

Diameters of poorly decomposed stumps have demonstrated to work as a good proxy for the dbh that dead trees had prior to their felling. Thus, fresh stumps can be used for inferring part of the recent history of tree populations. For our study, we infer that Alpine strong winds played a random-and-systematic mortality role where more dead trees belonged to size classes with larger numbers of individuals. The same should have occurred to Larix decidua on plots $\mathrm{K} 1$ and $\mathrm{K} 2$ as well as to Picea abies on plot K2. Yet the type-a pattern of comparisons when using Pinus sylvestris_K6 instead of Picea abies_K6 as a control suggests that $P$. abies_K6 was comparatively more "sensitive" to mass death. We do not propose the later was due to any particularities of wood characteristics of $P$. abies. Instead, many dead $P$. abies were tall, emergent individuals directly exposed to winds. During their fell, such large trees may have knocked neighboring, smaller ones. That may have produced our observed departure from the "random-and-systematic" effect of winds for P. abies on plot K6. The latter is indirectly supported by the fact that, the same species (P. abies) displayed a random-systematic mortality fashion on plot K2, where we saw no emergent individuals.

Our type a results for Alpine Larix decidua and Picea abies where storm Vaia did not cause mass mortality (plots K1 and K2) are very plausibly due to strong winds prior to such a storm. Firstly, because logging and clear-cutting are prohibited in our Alpine study site. Secondly, because we did not find any sign of other, previous disturbances like landslides or avalanches. On the Amazonian side, we found no signals of landslides occurring in the past (e.g., tracks of removed soil). We observed no case of strong winds during our time living in the Amazon (2014-2015), and found no register of strong winds striking the area in the past. In contrast, selective logging is a generalized custom in our Amazonian place. Thus, responses type-a by Piptocoma discolor, Vochysia bracelineae, Miconia decurrens and Pseudobombax sp seem to complete our published land-use histories of plots B, C, and $\mathrm{D}$ by suggesting that such species were subjected to discrete events of compulsive logging made by land-users during secondary succession. Humans are a species whose populations are well censused. By looking into the literature, we notice that the overall population structure of our tree species, including the ups-anddowns of many of our type-a histograms (Fig. 5), are comparable to the population of humans tragically loosing $20 \%$ of their total population during a war (Kugler et al., 2013; Fig. 6) and to a laboratory-grown snail species steadily suffering strong mortality as well (Saha et al., 2017). This comparison with species completely different to trees indirectly reinforces the plausibility of events of 

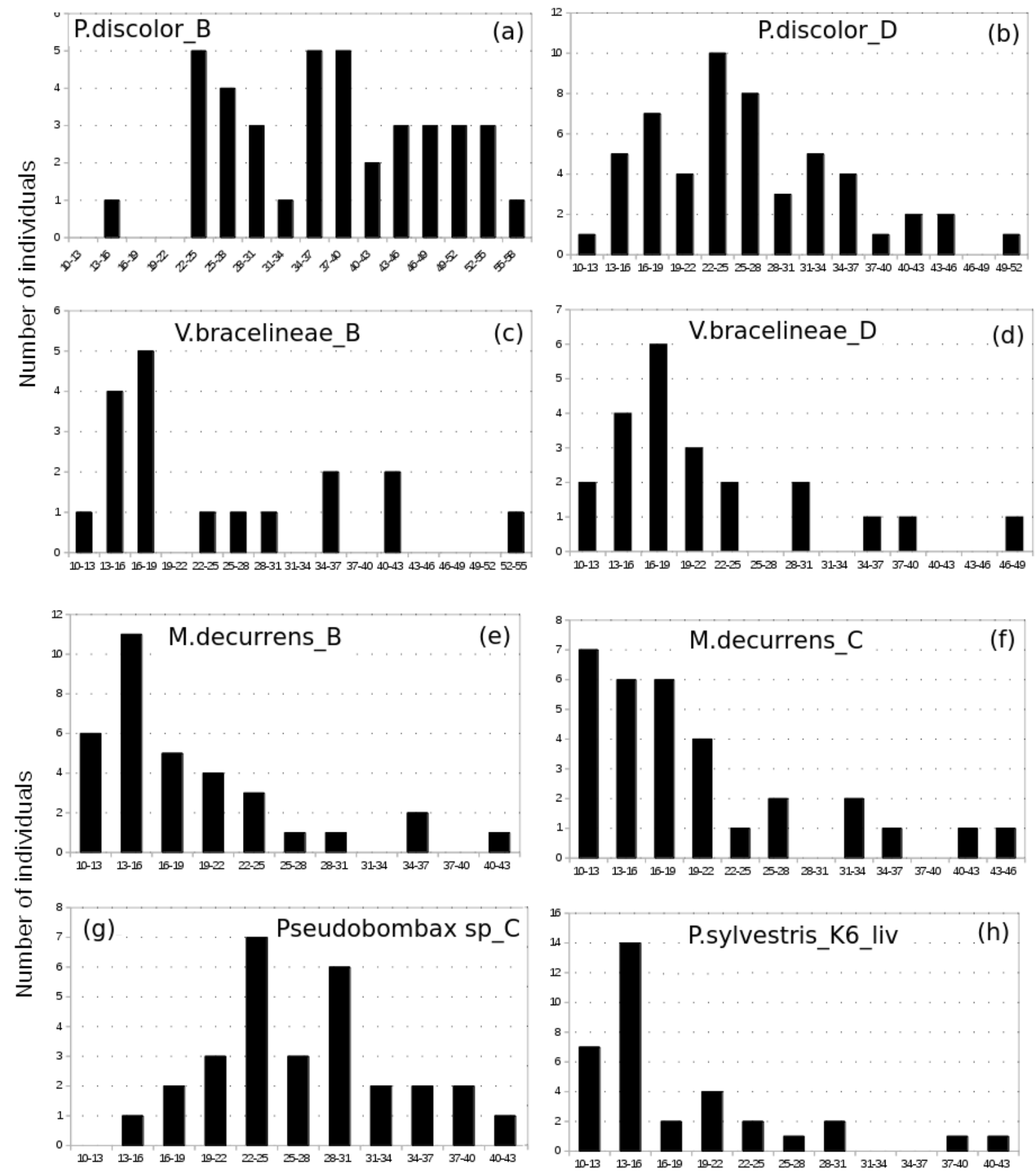

dbh classes $(\mathrm{cm})$

Fig. 5. Population structures for living trees ( $\geq 10$ diameter at breast height) of four Amazonian Tropical Rainforest species (a-g), plus one Alpine species (Pinus sylvestris) on studied plot K6 (Kühbergl, Italy). The alpine individuals survived mass mortality by strong winds by storm Vaia (October 27 to November 1, 2018). All the Amazonian size distributions were similar to the Alpine one (Kolmogorov-Smirnov tests, $\mathrm{p} \geq 0.1$ ), but not after including alpine dead individuals. Such a size-class change response type a (Fig. 1) suggests that similarities of shown Amazonian vs Alpine population structures may have resulted from mass mortality in the Amazonian site (Atacapi, Province of Napo, Ecuador). 
mass mortality during the past to have structured current populations of our Alpine and Amazonian trees.

Beyond the Alps and the Amazon, we consider that our historically-based study can help to explain results obtained by other works. In concrete, the population structure of $P$. sylvestris on our plot stroke by storm Vaia (K6) was similar to what Godínez-Ibarra, López-Mata (2002) identified as a population structure type IV for Bursera simarouba (L., Burseraceae) in Veracruz, Mexico. The same is valid for the endemic palm Ceroxylon echinulatum inhabiting the Andean Tropical Montane Cloud Forest in Pichincha, Ecuador; particularly when settled on pastures (Anthelme et al., 2011). Since Bursera simarouba and Ceroxylon echinulatum are widely used by people, we propose that humans are responsible of such population structures. In concrete, people may have selectively extracted Bursera simarouba (e.g., for live fences) and incidentally killed Ceroxylon echinulatum after annually cutting young leaves for handcraft (Montúfar et al., 2013). Our Amazonian Miconia decurrens on plot B has shown GodínezIbarra's population structures type IV too, making plausible to consider that human intervention generated that for the just mentioned species.

Since Bongers et al. (1988) proposed non-human-induced changes structuring tree populations, we find pertinent to consider Bonger's proposed mechanisms in relation to our results. Bongers' population structure I (more individuals in the first and second size classes) results from vigorous recruitment of young individuals besides low mortality so the population is very young. That generates a continuous histogram with no ups-anddowns nor bars lacking (Rockwood, 2006). In contrast, many of our histograms have peaks, valleys, and lacking bars. These makes Bongers' population structure type II to look similar to the ones we found for many species (Fig. 5). Bongers et al. (1988) propose this can be due to several causes. (a) Differential mortality where individuals belonging to some size classes die more than others. We consider that humans can have produced such a mortality in the Amazon by cutting trees of some sizes more than others. (b) Size-dependent growth rate of the individuals can generate more than one peak on the histogram of the species. (c) Periodic, temporal changes of the characteristics of the (micro)habitat can result in periods of vigorous growth of the individuals alternated with periods of low growth (Anthelme et al., 2011; Bongers et al., 1988). Our data cannot confirm whether mechanisms (b) and (c) have occurred, neither in the Amazon, nor in the Alps.

\section{Conclusion}

Human intervention is to be considered as a driving force determining tree population structures in forests. Further, long-term studies are needed to determine the relative importance of human intervention respect to other processes like microclimatic change, alternated vigor of individual growth, and mortality causes other than humans. Such research will help to complete the history of the change of both tree-population structures and whole forest communities. Meanwhile, looking into the history of tree populations as part of land-use history can propel research for answering some basic questions of Ecology: what are the agents altering population structure, and which population structuring agents are more influential than others.
Acknowledgements

Land owners in Atacapi, Ecuador, politely allowed us to perform our research on their lands. Robert Schifferegger and Andreas Oberhofer, of the Forest Department of the Province of South Tyrol and the Historical Archives of Bruneck, kindly allowed our work and supplied valuable historical information.

\section{References}

Anthelme, F., Lincango, J., Gully, C., Duarte, N. \& Montúfar R. (2011). How anthropogenic disturbances affect the resilience of a keystone palm tree in the threatened Andean cloud forest? Biological Conservation, 144, 1059-1067. DOI: 10.1016/j.biocon.2010.12.025.

Autonome Provinz Bozen-Südtirol (2019). Sturmschäden: Situationsbericht derLandesforstabteilung. http://www.provinz.bz.it/landforstwirtschaft/landwirtschaft/aktuelles.asp?aktuelles_action $=4 \&$ aktuelles_article_id=620762

Bongers, F., Popma, J., Del Castillo, J.M. \& Carabias J. (1988). Structure and floristic composition of the lowland rain forest of Los Tuxtlas, Mexico. Vegetatio, 74(1), 55-80. DOI: 10.1007/BF00045614.

Bürgi, M., Östlund, L. \& Mladenoff D.J. (2016). Legacy effects of human land-use:ecosystems as time-lagged systems. Ecosystems, 20(1), 94-103. DOI: 10.1007/s10021-016-0051-6.

Clinebell, R.R., Phillips, O.L., Gentry, A.H., Stark, N. \& Zuuring H. (1995). Predictionof neotropical tree and liana species richness from soil and climatic data. Biodiversity \& Conservation, 4(1), 56-90. DOI: 10.1007/ BF00115314.

Garrido-Pérez, E.I., Tella-Ruiz, D., Rojas-Salvatierra, J., Grefa, F.R., Díaz, L., Bonilla, K. \& Grefa J. (2017). Human intervention, neutral theory, and the assembly of Amazonian secondary forest communities in Napo, Ecuador. International Journal of Science and Nature, 8(3), 418-429.

Garrido-Pérez, E.I., Sidali, K.L., Rojas-Salvatierra, J., Tella-Ruíz, D., Cajas, Á. \& Peña M.S. (2018). Lecciones ecológicas de la historia amazónica: impacto diferencial del uso del suelo en las estructuras y biomasas aéreas de bosques secundarios en Napo, Ecuador. Bosque (Valdivia), 39(1), 37-48. DOI: 10.4067/S0717-92002018000100037.

Global Wind Atlas (2018). https://globalwindatlas.info/.

Godínez-Ibarra, O. \& López-Mata L. (2002). Estructura, composición, riqueza y diversidad de árboles en tres muestras de selva mediana subperennifolia. Anales del Instituto de Biología, Serie Botánica, 73(2), 283-314.

Holdridge, L.R., Grenke, W., Hatheway, W.H., Liang, T. \& Tosi J.A. (1971). Forest environments in tropical life zones: a pilot study. Oxford: Pergamon.

Jenny, H., Gessel, S.P. \& Bingham F.T. (1949). Comparative study of decomposition rates of organic matter in temperate and tropical regions. Soil Science, 68(6), 419-432. DOI: 10.1097/00010694-194912000-00001.

Kottek, M., Grieser, J., Beck, C., Rudolf, B. \& Rubel F. (2006). World map of the Köppen-Geiger climate classification updated. Meteorologische Zeitschrift, 15(3), 259-263. DOI: 10.1127/0941-2948/2006/0130.

Kugler, T., Kook Kang, K., Kugler, J., Arbetman-Rabinowitz, M. \& Thomas J. (2013). Demographic and economic consequences of conflict. International Studies Quarterly, 57(1), 1-12. DOI: 10.1111/isqu.12002.

Land Tirol (2019a). Bruneck und Umgebung -1581, in Historische Karten Tirol. https://maps.tirol.gv.at/HIK/.

Land Tirol (2019b). Spezialkarte 1:75000 1925-1934, in Historische Karten Tirol. https://maps.tirol.gv.at/HIK/.

Levis, C., Costa, F. R., Bongers, F., Peña-Claros, M., Clement, C. R., Junqueira, A. B. and other 146 authors. (2017). Persistent effects of pre-Columbian plant domestication on Amazonian forest composition. Science, 355(6328), 925-931. DOI: 10.1126/science.aal0157.

MAGAP-Ministerio de Agricultura, Ganadería, Acuacultura y Pesca (2011). Mapa de suelos del Ecuador continental (variable taxonomía) escala 1:250.000.

Meinzer, F.C., James, S.A. \& Goldstein G. (2004). Dynamics of transpiration, sap flow and use of stored water in tropical forest canopy trees. Tree Physiology, 24(8), 901-909. DOI: 10.1093/treephys/24.8.901.

Mikloš, M., Vyskot, I., Šatala, T., Korísteková, K., Jančo, M. \& Škvarenina J. (2017). Effect of forest ecosystems on the snow water equivalent in relation to aspect and elevation in the Hučava river watershed, Polana Biosphere Reserve (Slovakia). Ekológia (Bratislava), 36(3), 268-280. DOI: 10.1515/eko-2017-0022. 
Montúfar, R., Anthelme, F. \& Duarte N. (2013). Palma de Ramos-Ceroxylon echinulatum. In R. Valencia, R. Montúfar, H. Navarrete \& H. Balslev (Eds.), Palmas Ecuatorianas: Biolo-gía y uso sostenible (pp. 123-134) Quito, Ecuador: Publicaciones del Herbario QCA de la Pontificia Universidad Católica del Ecuador.

Oberhofer, A. (2017). Hermann Mahl (1860-1944): Ansätze für eine Biografie. In A. Oberhofer (Ed.), Hermann Mahl (1860-1944) - Pionier der Farbfotografie in Pustertal (pp. 15-36). Bruneck, South Tyro: Verein für Kultur und Heimatpflege Bruneck.

Pérez-Paredes, M.G., Sánchez-González, A. \& Tejero-Díez J.D. (2014). Estructura poblacional y características del hábitat de dos especies de Cyatheaceae del estado de Hidalgo, México. Botanical Sciences, 92(2), 259-271. DOI: 10.17129/botsci.48

Rockwood, L.L. (2006). Introduction to population ecology. Malden: John Wiley \& Sons.

Saha, C., Parveen, S., Chakraborty, J., Pramanik, S. \& Aditya G. (2017). Life table estimates of the invasive snail Physa acuta Draparnaud, 1805, oc curring in India. Ekológia (Bratislava), 36(1), 60-68. DOI: 10.1515/eko2017-0006.
Szabó, P. \& Hédl R. (2011). Advancing the integration of history and ecology for conservation. Conservation Biology, 25(4), 680-687. DOI: 10.1111/j.1523-1739.2011.01710.x

Thaiutsa, B. \& Granger O. (1979). Climate and the decomposition rate of tropical forest litter. Unasylva, 126, 28-38. http://www.fao.org/3/n6845e/ n6845e $05 . h t m$.

Vitery, P.V. (2015). Women as creators of biodiverse forests: Ecuadorian Amazon - ancestral system chakra ushun purun. United Nations Framework Convention on Climate Change. https://unfccc.int/sites/default/ files/07_vitery_reddplus_ecuador.pdf.

Víquez, E. \& Pérez D. (2005). Effect of pruning on tree growth, yield, and wood properties of Tectona grandis plantations in Costa Rica. Silva Fennica, 39(3), 381. DOI: 10.14214/sf.375.

World Climate Data (2019a). Tena data. https://es.climate-data.org/location/2977/.

World Climate Data (2019b). Bruneck data. https://en.climate-data.org/ europe/italy/trentino-alto-adige-suedtirol/bruneck-13590/\#climategraph. 


\section{Appendix}

Output of pairwise Kolmogorov-Smirnov tests comparing size class distributions for tree species among four Amazonian (A to D) and three Alpine (K1, K2 and K6) species. Amazonian place: Atacapi, Napo, Ecuador; Alpine place: Kühbergl, South Tyrol, Italy. $\mathrm{n}=$ number of individuals. liv $=$ analysis run for: living individuals, all $=$ analysis run for living + dead individuals for which dbh was estimated according to table 2 . Bold characters $=$ statistically significant differences at significant level $\alpha=0.95$. Gray shade: species for which death date was directly observed (October 27 to November 1, 2018).

(a) Amazonian vs Alpine species.

\begin{tabular}{|c|c|c|c|c|c|c|c|c|c|c|c|}
\hline & $\begin{array}{l}\text { L. decidua } \\
\text { (K1-liv); } \\
\text { n=39 }\end{array}$ & $\begin{array}{l}\text { L. decidua } \\
\text { (K2-liv); } \\
\text { n=35 }\end{array}$ & \begin{tabular}{|c|} 
L. decidua \\
(K1-all); \\
$\mathrm{n}=80$
\end{tabular} & $\begin{array}{c}\text { L. decidua } \\
\text { (K2-all); } \\
\mathrm{n}=58\end{array}$ & $\begin{array}{c}\text { P. abies } \\
\text { (K2-liv-all); } \\
\mathrm{n}=43\end{array}$ & $\begin{array}{c}\text { P. abies } \\
\text { (K6-liv); } \\
\mathrm{n}=34\end{array}$ & $\begin{array}{c}\begin{array}{c}\text { P. abies } \\
\text { (K6-all); } \\
\mathrm{n}=70\end{array} \\
\end{array}$ & $\begin{array}{l}\text { P. sylvestris } \\
\text { (K2-liv); } \\
\mathrm{n}=20\end{array}$ & $\begin{array}{l}\text { P. sylvestris } \\
\text { (K2-all); } \\
\mathrm{n}=27\end{array}$ & $\begin{array}{c}\text { P. sylvestris } \\
\text { (K6-liv); } \\
\mathrm{n}=43\end{array}$ & $\begin{array}{l}\text { P. sylvestris } \\
\text { (K6-all); } \\
\mathrm{n}=105\end{array}$ \\
\hline $\begin{array}{l}\text { P. discolor (A); } \\
\mathrm{n}=123\end{array}$ & $\begin{array}{c}\mathrm{D}=0.8 \\
\mathrm{p}<0.001\end{array}$ & $\begin{array}{l}\mathrm{D}=0.6 \\
\mathrm{p}=0.01\end{array}$ & $\begin{array}{c}\mathrm{D}=0.6 \\
\mathrm{p}=0.001\end{array}$ & $\begin{array}{l}\mathrm{D}=0.5 \\
\mathrm{p}=0.03\end{array}$ & $\begin{array}{c}\mathrm{D}=0.6 \\
\mathrm{p}=0.003\end{array}$ & $\begin{array}{c}\mathrm{D}=0.6 \\
\mathrm{p}=0.001\end{array}$ & $\begin{array}{c}D=0.6 \\
p=0.009\end{array}$ & $\begin{array}{c}\mathrm{D}=0.8 \\
\mathrm{p}<0.001\end{array}$ & $\begin{array}{c}\mathrm{D}=0.7 \\
\mathrm{p}=\mathbf{0 . 0 0 1}\end{array}$ & $\begin{array}{l}\mathrm{D}=0.4 \\
\mathrm{p}=0.1\end{array}$ & $\begin{array}{c}\mathrm{D}=0.7 \\
\mathrm{p}<0.001\end{array}$ \\
\hline $\begin{array}{l}\text { P. discolor }(\mathrm{B}) ; \\
\mathrm{n}=39\end{array}$ & $\begin{array}{l}D=0.4 \\
p=0.03\end{array}$ & $\begin{array}{l}\mathrm{D}=0.2 \\
\mathrm{p}=0.9\end{array}$ & & $\begin{array}{l}\mathrm{D}=0.2 \\
\mathrm{p}=0.7\end{array}$ & & $\begin{array}{l}\mathrm{D}=0.3 \\
\mathrm{p}=0.6\end{array}$ & $\begin{array}{l}\mathrm{D}=0.2 \\
\mathrm{p}=0.6\end{array}$ & & $\begin{array}{c}\mathrm{D}=0.7 \\
\mathrm{p}=0.001\end{array}$ & $\begin{aligned} \mathrm{D} & =0.2 \\
\mathrm{p} & =0.7\end{aligned}$ & $\begin{array}{c}\mathrm{D}=0.5 \\
\mathrm{p}=0.003\end{array}$ \\
\hline $\begin{array}{l}\text { P. discolor }(\mathrm{D}) ; \\
\mathrm{n}=53\end{array}$ & $\begin{array}{l}D=0.4 \\
p=0.03\end{array}$ & $\begin{array}{l}\mathrm{D}=0.2 \\
\mathrm{p}=0.9\end{array}$ & $\begin{array}{l}D=0.4 \\
p=0.03\end{array}$ & $\begin{array}{l}\mathrm{D}=0.1 \\
\mathrm{p}=0.9\end{array}$ & $\begin{array}{l}\mathrm{D}=0.4 \\
\mathrm{p}=0.1\end{array}$ & $\begin{array}{l}\mathrm{D}=0.3 \\
\mathrm{p}=0.6\end{array}$ & $\begin{array}{l}\mathrm{D}=0.2 \\
\mathrm{p}=0.4\end{array}$ & $\begin{array}{l}D=0.5 \\
p=0.02\end{array}$ & $\begin{array}{l}\mathrm{D}=0.4 \\
\mathrm{p}=0.05\end{array}$ & $\begin{array}{l}\mathrm{D}=0.3 \\
\mathrm{p}=0.7\end{array}$ & $\begin{array}{c}\mathrm{D}=0.6 \\
\mathrm{p}<0.001\end{array}$ \\
\hline $\begin{array}{l}\text { V. bracelineae }(\mathrm{B}) ; \\
\mathrm{n}=18\end{array}$ & $\begin{array}{c}\mathrm{D}=0.09 \\
\mathrm{p}=0.9\end{array}$ & $\begin{array}{l}D=0.6 \\
p=0.02\end{array}$ & $\begin{array}{c}\mathrm{D}=0.1 \\
\mathrm{p}=0.9\end{array}$ & $\begin{array}{c}\mathrm{D}=0.4 \\
\mathrm{p}=0.1\end{array}$ & $\begin{array}{l}\mathrm{D}=0.2 \\
\mathrm{p}=0.9\end{array}$ & $\begin{array}{l}\mathrm{D}=0.3 \\
\mathrm{p}=0.6\end{array}$ & $\begin{array}{l}\mathrm{D}=0.3 \\
\mathrm{p}=0.5\end{array}$ & & $\begin{array}{l}\mathrm{D}=0.1 \\
\mathrm{p}=0.9\end{array}$ & $\begin{array}{l}\mathrm{D}=0.4 \\
\mathrm{p}=0.3\end{array}$ & $\begin{array}{l}\mathrm{D}=0.3 \\
\mathrm{p}=0.3\end{array}$ \\
\hline $\begin{array}{l}\text { V. bracelineae }(\mathrm{C}) \\
\mathrm{n}=104\end{array}$ & $\begin{array}{c}\mathrm{D}=0.6 \\
\mathrm{p}<0.001\end{array}$ & $\begin{array}{l}\mathrm{D}=0.4 \\
\mathrm{p}=0.2\end{array}$ & $\begin{array}{c}\mathrm{D}=0.6 \\
\mathrm{p}<0.001\end{array}$ & $\begin{array}{l}\mathrm{D}=0.3 \\
\mathrm{p}=0.3\end{array}$ & $\begin{array}{c}\mathrm{D}=0.5 \\
\mathrm{p}=0.009\end{array}$ & $\begin{array}{l}D=0.5 \\
p=0.04\end{array}$ & $\begin{array}{l}D=0.4 \\
p=0.03\end{array}$ & $\begin{array}{c}\mathrm{D}=\mathbf{0 . 7} \\
\mathrm{p}<\mathbf{0 . 0 0 1}\end{array}$ & $\begin{array}{c}\mathrm{D}=0.7 \\
\mathrm{p}=<\mathbf{0 . 0 0 1}\end{array}$ & $\begin{array}{l}\mathrm{D}=0.3 \\
\mathrm{p}=0.4\end{array}$ & $\begin{array}{c}D=0.6 \\
p=<0.001\end{array}$ \\
\hline $\begin{array}{l}\text { V. bracelineae }(\mathrm{D}) ; \\
\mathrm{n}=22\end{array}$ & $\begin{array}{l}\mathrm{D}=0.1 \\
\mathrm{p}=0.9\end{array}$ & $\begin{aligned} \mathrm{D} & =0.4 \\
\mathrm{p} & =0.3\end{aligned}$ & $\begin{array}{c}\mathrm{D}=0.2 \\
\mathrm{p}=0.8\end{array}$ & $\begin{array}{c}\mathrm{D}=0.3 \\
\mathrm{p}=0.5\end{array}$ & $\begin{array}{c}\mathrm{D}=0.1 \\
\mathrm{p}=0.9\end{array}$ & $\begin{array}{l}\mathrm{D}=0.2 \\
\mathrm{p}=0.9\end{array}$ & $\begin{array}{l}\mathrm{D}=0.3 \\
\mathrm{p}=0.6\end{array}$ & $\begin{array}{l}\mathrm{D}=0.2 \\
\mathrm{p}=0.9\end{array}$ & $\begin{array}{l}\mathrm{D}=0.1 \\
\mathrm{p}=0.1\end{array}$ & $\begin{array}{l}\mathrm{D}=0.3 \\
\mathrm{p}=0.7\end{array}$ & $\begin{array}{l}\mathrm{D}=0.4 \\
\mathrm{p}=0.08\end{array}$ \\
\hline $\begin{array}{l}\text { M. decurrens }(\mathrm{B}) ; \\
\mathrm{n}=34\end{array}$ & $\begin{array}{c}\mathrm{D}=0.3 \\
\mathrm{p}=0.3\end{array}$ & $\begin{array}{l}\mathrm{D}=0.3 \\
\mathrm{p}=0.6\end{array}$ & $\begin{array}{l}\mathrm{D}=0.3 \\
\mathrm{p}=0.3\end{array}$ & $\begin{array}{l}\mathrm{D}=0.1 \\
\mathrm{p}=0.9\end{array}$ & $\begin{array}{l}\mathrm{D}=0.2 \\
\mathrm{p}=0.8\end{array}$ & $\begin{array}{l}\mathrm{D}=0.2 \\
\mathrm{p}=0.9\end{array}$ & $\begin{array}{c}\mathrm{D}=0.1 \\
\mathrm{p}=0.9\end{array}$ & $\begin{array}{c}\mathrm{D}=0.4 \\
\mathrm{p}=0.2\end{array}$ & $\begin{array}{l}\mathrm{D}=0.3 \\
\mathrm{p}=0.4\end{array}$ & $\begin{array}{l}\mathrm{D}=0.2 \\
\mathrm{p}=0.9\end{array}$ & $\begin{array}{l}D=0.5 \\
p=0.01\end{array}$ \\
\hline $\begin{array}{l}\text { M. decurrens }(\mathrm{C}) ; \\
\mathrm{n}=31\end{array}$ & $\begin{array}{c}\mathrm{D}=0.2 \\
\mathrm{p}=0.9\end{array}$ & $\begin{array}{l}\mathrm{D}=0.3 \\
\mathrm{p}=0.3\end{array}$ & $\begin{array}{l}\mathrm{D}=0.3 \\
\mathrm{p}=0.6\end{array}$ & $\begin{array}{c}\mathrm{D}=0.3 \\
\mathrm{p}=0.3\end{array}$ & $\begin{array}{l}\mathrm{D}=0.1 \\
\mathrm{p}=0.9\end{array}$ & $\begin{array}{c}\mathrm{D}=0.2 \\
\mathrm{p}=0.8\end{array}$ & $\begin{array}{c}\mathrm{D}=0.1 \\
\mathrm{p}=0.9\end{array}$ & $\begin{array}{l}\mathrm{D}=0.4 \\
\mathrm{p}=0.2\end{array}$ & $\begin{array}{l}\mathrm{D}=0.3 \\
\mathrm{p}=0.4\end{array}$ & $\begin{array}{l}\mathrm{D}=0.2 \\
\mathrm{p}=0.9\end{array}$ & $\begin{array}{l}\mathrm{D}=0.5 \\
\mathrm{p}=0.01\end{array}$ \\
\hline $\begin{array}{l}\text { Pseudobombax } \mathrm{sp} \\
\text { (C); } \mathrm{n}=29\end{array}$ & $\begin{array}{l}\mathrm{D}=0.4 \\
\mathrm{p}=0.2\end{array}$ & $\begin{array}{l}\mathrm{D}=0.1 \\
\mathrm{p}=0.9\end{array}$ & $\begin{array}{l}\mathrm{D}=0.4 \\
\mathrm{p}=0.08\end{array}$ & $\begin{array}{c}\mathrm{D}=0.2 \\
\mathrm{p}=0.8\end{array}$ & $\begin{array}{c}\mathrm{D}=0.4 \\
\mathrm{p}=0.1\end{array}$ & $\begin{array}{c}\mathrm{D}=0.2 \\
\mathrm{p}=0.9\end{array}$ & $\begin{array}{c}\mathrm{D}=0.3 \\
\mathrm{p}=0.5\end{array}$ & $\begin{array}{l}\mathrm{D}=0.5 \\
\mathrm{p}=0.07\end{array}$ & $\begin{array}{l}\mathrm{D}=0.4 \\
\mathrm{p}=0.3\end{array}$ & $\begin{array}{c}\mathrm{D}=0.2 \\
\mathrm{p}=0.8\end{array}$ & $\begin{array}{c}D=0.6 \\
p=0.002\end{array}$ \\
\hline
\end{tabular}

(b) Alpine species.

\begin{tabular}{|c|c|c|c|c|c|c|c|c|c|c|c|}
\hline & $\begin{array}{l}\text { L. decidua } \\
\text { (K1-liv); } \\
\text { n=39 }\end{array}$ & $\begin{array}{l}\text { L. decidua } \\
\text { (K2-liv); } \\
\text { n=35 }\end{array}$ & $\begin{array}{c}\text { L. decidua } \\
\text { (K1-all); } \\
\mathrm{n}=80\end{array}$ & $\begin{array}{l}\text { L. decidua } \\
\text { (K2-all); } \\
\text { n=58 }\end{array}$ & $\begin{array}{c}\text { P. abies } \\
\text { (K2-liv-all); } \\
\text { n=43 }\end{array}$ & $\begin{array}{c}\text { P. abies } \\
\text { (K6-liv); } \\
\mathrm{n}=34\end{array}$ & $\begin{array}{c}\text { P. abies } \\
\text { (K6-all); } \\
\mathrm{n}=70\end{array}$ & $\begin{array}{l}\text { P. sylvestris } \\
\text { (K2-liv); } \\
\mathrm{n}=20\end{array}$ & $\begin{array}{l}\text { P. sylvestris } \\
\text { (K2-all); } \\
\mathrm{n}=27\end{array}$ & $\begin{array}{l}\text { P. sylvestris } \\
\text { (K6-liv); } \\
\mathrm{n}=43\end{array}$ & $\begin{array}{l}\text { P. sylvestris } \\
\text { (K6-all); } \\
\text { n=105 }\end{array}$ \\
\hline $\begin{array}{l}\text { L. decidua } \\
\text { (K1-liv); } \\
\mathrm{n}=39\end{array}$ & $\begin{array}{c}D=0, \\
p=1\end{array}$ & $\begin{array}{l}D=0.5 \\
p=0.02\end{array}$ & $\begin{array}{l}\mathrm{D}=0.1, \\
\mathrm{p}=0.8\end{array}$ & $\begin{array}{l}D=0.3 \\
p=0.02\end{array}$ & $\begin{array}{l}\mathrm{D}=0.1 \\
\mathrm{p}=0.9\end{array}$ & $\begin{array}{c}\mathrm{D}=.0 .3 \\
\mathrm{p}=0.5\end{array}$ & $\begin{array}{l}\mathrm{D}=0.2 \\
\mathrm{p}=0.4\end{array}$ & $\begin{array}{l}\mathrm{D}=0.1, \\
\mathrm{p}=0.9\end{array}$ & $\begin{array}{l}\mathrm{D}=0.2 \\
\mathrm{p}=0.7\end{array}$ & $\begin{array}{l}\mathrm{D}=0.4 \\
\mathrm{p}=0.1\end{array}$ & $\begin{array}{c}\mathrm{D}=0.2, \\
\mathrm{p}=0.2\end{array}$ \\
\hline $\begin{array}{l}\text { L. decidua } \\
\text { (K2-liv); } \\
\mathrm{n}=35\end{array}$ & & $\begin{array}{c}D=0 \\
p=1\end{array}$ & $\begin{array}{l}D=0.5 \\
p=0.01\end{array}$ & $\begin{array}{l}\mathrm{D}=0.2 \\
\mathrm{p}=0.9\end{array}$ & $\begin{array}{l}D=0.5 \\
p=0.02\end{array}$ & $\begin{array}{l}\mathrm{D}=0.3 \\
\mathrm{p}=0.6\end{array}$ & $\begin{array}{c}\mathrm{D}=0.4, \\
\mathrm{p}=0.1\end{array}$ & $\begin{array}{c}D=0.6 \\
p=0.009\end{array}$ & $\begin{array}{l}D=0.5 \\
p=0.06\end{array}$ & $\begin{array}{l}\mathrm{D}=0.3 \\
\mathrm{p}=0.4\end{array}$ & $\begin{array}{c}\mathrm{D}=\mathbf{0 7} \\
\mathbf{p}<\mathbf{0 . 0 0 1}\end{array}$ \\
\hline $\begin{array}{l}\text { L. decidua } \\
\text { (K1-all); } \\
\mathrm{n}=80\end{array}$ & & & $\begin{array}{c}D=0, \\
p=1\end{array}$ & $\begin{array}{c}\mathrm{D}=0.3 \\
\mathrm{p}=0.1\end{array}$ & $\begin{array}{c}\mathrm{D}=0.2 \\
\mathrm{p}=0.8\end{array}$ & $\begin{array}{l}\mathrm{D}=0.3, \\
\mathrm{p}=0.3\end{array}$ & $\begin{array}{l}\mathrm{D}=0.2 \\
\mathrm{p}=0.5\end{array}$ & $\begin{array}{l}\mathrm{D}=0.2 \\
\mathrm{p}=0.8\end{array}$ & $\begin{array}{l}\mathrm{D}=0.2 \\
\mathrm{p}=0.4\end{array}$ & $\begin{array}{l}\mathrm{D}=0.3 \\
\mathrm{p}=0.4\end{array}$ & $\begin{array}{l}\mathrm{D}=0.2, \\
\mathrm{p}=0.3\end{array}$ \\
\hline $\begin{array}{l}\text { L. decidua } \\
\text { (K2-all); } \\
\mathrm{n}=58\end{array}$ & & & & $\begin{array}{l}D=0, \\
p=1\end{array}$ & $\begin{array}{c}\mathrm{D}=0.3 \\
\mathrm{p}=0.2\end{array}$ & $\begin{array}{l}\mathrm{D}=0.2, \\
\mathrm{p}=0.9\end{array}$ & $\begin{array}{l}\mathrm{D}=0.2, \\
\mathrm{p}=0.7\end{array}$ & $\begin{array}{l}\mathrm{D}=0.4 \\
\mathrm{p}=0.07\end{array}$ & $\begin{array}{l}\mathrm{D}=0.4 \\
\mathrm{p}=0.1\end{array}$ & $\begin{array}{l}\mathrm{D}=0.2 \\
\mathrm{p}=0.9\end{array}$ & $\begin{array}{c}D=0.5 \\
p=0.002\end{array}$ \\
\hline $\begin{array}{l}\text { P. abies } \\
\text { (K2-liv-all); } \\
\mathrm{n}=43\end{array}$ & & & & & $\begin{array}{l}D=0, \\
p=1\end{array}$ & $\begin{array}{l}\mathrm{D}=0.2, \\
\mathrm{p}=0.8\end{array}$ & $\begin{array}{l}\mathrm{D}=0.2, \\
\mathrm{p}=0.8\end{array}$ & $\begin{array}{l}\mathrm{D}=0.2, \\
\mathrm{p}=0.7\end{array}$ & $\begin{array}{l}\mathrm{D}=0.2 \\
\mathrm{p}=0.9\end{array}$ & $\begin{array}{l}\mathrm{D}=0.3 \\
\mathrm{p}=0.6\end{array}$ & $\begin{array}{l}D=0.4 \\
p=0.04\end{array}$ \\
\hline $\begin{array}{l}\text { P. abies } \\
\text { (K6-liv); } \\
\mathrm{n}=34\end{array}$ & & & & & & $\begin{array}{c}D=0, \\
p=1\end{array}$ & $\begin{array}{l}\mathrm{D}=0.1, \\
\mathrm{p}=0.9\end{array}$ & $\begin{array}{l}\mathrm{D}=0.3 \\
\mathrm{p}=0.6\end{array}$ & $\begin{array}{l}\mathrm{D}=0.2 \\
\mathrm{p}=0.8\end{array}$ & $\begin{array}{l}\mathrm{D}=0.2 \\
\mathrm{p}=0.9\end{array}$ & $\begin{array}{l}D=0.5 \\
p=0.01\end{array}$ \\
\hline $\begin{array}{l}\text { P. abies } \\
\text { (K6-all); } \\
\mathrm{n}=70\end{array}$ & & & & & & & $\begin{array}{l}D=0, \\
p=1\end{array}$ & $\begin{array}{c}\mathrm{D}=0.3 \\
\mathrm{p}=0.2\end{array}$ & $\begin{array}{l}\mathrm{D}=0.3 \\
\mathrm{p}=0.3\end{array}$ & $\begin{array}{l}\mathrm{D}=0.2 \\
\mathrm{p}=0.9\end{array}$ & $\begin{array}{l}D=0.3 \\
p=0.04\end{array}$ \\
\hline $\begin{array}{l}\text { P. sylvestris } \\
\text { (K2-liv); } \\
\mathrm{n}=20\end{array}$ & & & & & & & & $\begin{array}{l}D=0, \\
p=1\end{array}$ & $\begin{array}{l}D=0.4, \\
p=0.04\end{array}$ & $\begin{array}{l}\mathrm{D}=0.4 \\
\mathrm{p}=0.1\end{array}$ & $\begin{array}{l}D=0.4, \\
p=0.04\end{array}$ \\
\hline $\begin{array}{l}\text { P. sylvestris } \\
\text { (K2-all); } \\
\mathrm{n}=27\end{array}$ & & & & & & & & & $\begin{array}{c}D=0, \\
p=1\end{array}$ & $\begin{array}{l}\mathrm{D}=0.4, \\
\mathrm{p}=0.2\end{array}$ & $\begin{array}{l}D=0.4 \\
p=0.01\end{array}$ \\
\hline $\begin{array}{l}\text { P. sylvestris } \\
\text { (K6-liv); } \\
\mathrm{n}=43\end{array}$ & & & & & & & & & & $\begin{array}{l}D=0 \\
p=1\end{array}$ & $\begin{aligned} \mathrm{D} & =0.4, \\
\mathrm{p} & =0.1\end{aligned}$ \\
\hline $\begin{array}{l}\text { P. sylvestris } \\
\text { (K6-all); } \\
\mathrm{n}=105\end{array}$ & & & & & & & & & & & $\begin{array}{l}D=0, \\
p=1\end{array}$ \\
\hline
\end{tabular}


Ekológia (Bratislava) 2021: 40(1): 37-47

(c) Amazonian species.

\begin{tabular}{|c|c|c|c|c|c|c|c|c|c|}
\hline & $\begin{array}{l}\begin{array}{l}\text { P. discolor } \\
\text { (A); } \\
\mathrm{n}=123\end{array} \\
\end{array}$ & $\begin{array}{l}\text { P. discolor } \\
\quad(\mathrm{B}) ; \\
\mathrm{n}=39\end{array}$ & $\begin{array}{l}\text { P. discolor } \\
\text { (D); } \mathrm{n}=53\end{array}$ & $\begin{array}{c}\text { V. bracelineae } \\
(\mathrm{B}) ; \\
\mathrm{n}=18\end{array}$ & $\begin{array}{c}\begin{array}{c}\text { V. bracelineae } \\
(\mathrm{C}) \\
\mathrm{n}=104\end{array} \\
\end{array}$ & $\begin{array}{c}\text { V. bracelineae } \\
(\mathrm{D}) ; \\
\mathrm{n}=22\end{array}$ & $\begin{array}{c}\text { M. decurrens } \\
\quad(\mathrm{B}) ; \\
\mathrm{n}=34\end{array}$ & $\begin{array}{c}\text { M. decurrens } \\
\quad(\mathrm{C}) ; \\
\mathrm{n}=31\end{array}$ & $\begin{array}{c}\text { Pseudobombax sp } \\
\text { (C); } \\
\mathrm{n}=29\end{array}$ \\
\hline $\begin{array}{l}\text { P. discolor (A); } \\
\mathrm{n}=123\end{array}$ & $\begin{array}{c}\mathrm{D}=0 \\
\mathrm{p}=1\end{array}$ & $\begin{array}{c}\mathrm{D}=0.6 \\
\mathrm{p}=0.005\end{array}$ & $\begin{array}{l}\mathrm{D}=0.5 \\
\mathrm{p}=0.07\end{array}$ & $\begin{array}{c}\mathrm{D}=0.8 \\
\mathbf{p}<0.001\end{array}$ & $\begin{array}{l}\mathrm{D}=0.4 \\
\mathrm{p}=0.2\end{array}$ & $\begin{array}{c}\mathrm{D}=\mathbf{0 . 7} \\
\mathrm{p}=\mathbf{0 . 0 0 4}\end{array}$ & $\begin{array}{l}D=0.5 \\
p=0.05\end{array}$ & $\begin{array}{l}D=0.6 \\
p=0.01\end{array}$ & $\begin{array}{l}\mathrm{D}=0.6 \\
\mathrm{p}=0.01\end{array}$ \\
\hline $\begin{array}{l}\text { P. discolor (B); } \\
\mathrm{n}=39\end{array}$ & & $\begin{array}{l}\mathrm{D}=0 \\
\mathrm{p}=1\end{array}$ & $\begin{array}{l}\mathrm{D}=0.2 \\
\mathrm{p}=0.7\end{array}$ & $\begin{array}{l}\mathrm{D}=0.4 \\
\mathrm{p}=0.4\end{array}$ & $\begin{array}{l}D=0.5 \\
p=0.03\end{array}$ & $\begin{array}{l}\mathrm{D}=0.3 \\
\mathrm{p}=0.3\end{array}$ & $\begin{array}{l}\mathrm{D}=0.2 \\
\mathrm{p}=0.9\end{array}$ & $\begin{array}{l}\mathrm{D}=0.2 \\
\mathrm{p}=0.8\end{array}$ & $\begin{array}{l}\mathrm{D}=0.2 \\
\mathrm{p}=0.9\end{array}$ \\
\hline $\begin{array}{l}\text { P. discolor (D); } \\
\mathrm{n}=53\end{array}$ & & & $\mathrm{D}=0, \mathrm{p}=1$ & $\begin{array}{l}\mathrm{D}=0.4 \\
\mathrm{p}=0.08\end{array}$ & $\begin{array}{l}\mathrm{D}=0.2 \\
\mathrm{p}=0.7\end{array}$ & $\begin{array}{l}\mathrm{D}=0.3 \\
\mathrm{p}=0.3\end{array}$ & $\begin{array}{l}\mathrm{D}=0.2 \\
\mathrm{p}=0.9\end{array}$ & $\begin{array}{l}\mathrm{D}=0.2 \\
\mathrm{p}=0.8\end{array}$ & $\begin{array}{l}\mathrm{D}=0.3 \\
\mathrm{p}=0.5\end{array}$ \\
\hline $\begin{array}{l}\text { V. bracelineae }(\mathrm{B}) ; \\
\mathrm{n}=18\end{array}$ & & & & $\begin{array}{c}\mathrm{D}=0 \\
\mathrm{p}=1\end{array}$ & $\begin{array}{c}D=0.6 \\
p=0.001\end{array}$ & $\begin{array}{l}\mathrm{D}=0.2 \\
\mathrm{p}=0.9\end{array}$ & $\begin{array}{c}\mathrm{D}=0.3 \\
\mathrm{p}=0.4\end{array}$ & $\begin{array}{l}\mathrm{D}=0.2 \\
\mathrm{p}=0.7\end{array}$ & $\begin{array}{l}\mathrm{D}=0.5 \\
\mathrm{p}=0.09\end{array}$ \\
\hline $\begin{array}{l}\text { V. bracelineae }(\mathrm{C}) ; \\
\mathrm{n}=104\end{array}$ & & & & & $\begin{array}{l}\mathrm{D}=0 \\
\mathrm{p}=1\end{array}$ & $\begin{array}{c}D=0.6 \\
p=0.008\end{array}$ & $\begin{array}{c}\mathrm{D}=0.36 \\
\mathrm{p}=0.3\end{array}$ & $\begin{array}{l}\mathrm{D}=0.4 \\
\mathrm{p}=0.08\end{array}$ & $\begin{array}{l}D=0.5 \\
p=0.02\end{array}$ \\
\hline $\begin{array}{l}\text { V. bracelineae (D); } \\
\mathrm{n}=22\end{array}$ & & & & & & $\begin{array}{l}\mathrm{D}=0 \\
\mathrm{p}=1\end{array}$ & $\begin{array}{l}\mathrm{D}=0.2 \\
\mathrm{p}=0.9\end{array}$ & $\begin{array}{l}\mathrm{D}=0.2 \\
\mathrm{p}=0.9\end{array}$ & $\begin{array}{l}\mathrm{D}=0.3 \\
\mathrm{p}=0.7\end{array}$ \\
\hline $\begin{array}{l}\text { M. decurrens (B); } \\
\mathrm{n}=34\end{array}$ & & & & & & & $\begin{array}{l}\mathrm{D}=0 \\
\mathrm{p}=1\end{array}$ & $\begin{array}{l}\mathrm{D}=0.1 \\
\mathrm{p}=0.9\end{array}$ & $\begin{array}{l}\mathrm{D}=0.2 \\
\mathrm{p}=0.9\end{array}$ \\
\hline $\begin{array}{l}\text { M. decurrens }(\mathrm{C}) ; \\
\mathrm{n}=31\end{array}$ & & & & & & & & $\begin{array}{l}\mathrm{D}=0 \\
\mathrm{p}=1\end{array}$ & $\begin{array}{l}\mathrm{D}=0.1 \\
\mathrm{p}=0.9\end{array}$ \\
\hline $\begin{array}{l}\text { Pseudobombax sp } \\
\text { (C); } \mathrm{n}=29\end{array}$ & & & & & & & & & $\begin{array}{l}\mathrm{D}=0 \\
\mathrm{p}=1\end{array}$ \\
\hline
\end{tabular}

